First public draft: Please use only within the context of REA-APPRRE discussions.

\title{
CULTIVATING A SPIRIT FOR JUSTICE AND PEACE: TEACHING THROUGH ORAL HISTORY
}

\author{
Claire Bischoff and Mary Elizabeth Mullino Moore \\ Emory University
}

The value of a person's life work is difficult to discern, much less to evaluate or to become a source of wisdom, if we reflect upon that work from the limited perspectives of our own experience or the dominant religious and educational theories of the day. Oral history provides a way to listen to another closely, to analyze that person's life and work in relation to a larger context, and to draw out insights for theory and practice.

---Syllabus, Prophetic Pioneers in Religious Education, Fall $2004^{1}$

How might educators teach for justice and peace in courses with diverse purposes and subjects? Is such teaching only approachable through courses with explicit justice and peace subject matter? If education has a major role in humanization and in contributing to a better world, then all courses should potentially contribute to justice and peace. We tested this possibility in a course called "Prophetic Pioneers in Religious Education"- - a course designed to "explore religious education history, issues, and visions through life story, contextual analysis, and educational theories, practices, and cultural 'products." 'The subjects of this class were people who pioneered in religious education in the past century, along with three living women whom the class interviewed to gather their stories and draw upon their wisdom.

The guiding thesis of this study is that teaching through oral history has potential to cultivate a spirit for justice and peace and to enlarge the pedagogical insights in current justice and peace literature. Such teaching can help students discover knowledge that informs and guides a just-peace spirit, develop skills that embody it, and prepare for the future. The claim here is not that oral history is the only way by which these goals can be met. We simply offer oral history as a distinctive educational approach that has value to equip people for life-giving relations with others, whether in education, ministry, public activism, or other vocations. To investigate this possibility, we analyze two sources that pertain to justice and peace - periodical literature focused explicitly on such education and a case study of the Prophetic Pioneers class. The hope is to discover pedagogical clues for teaching justice and peace that are more subtle and fulsome than those identified heretofore.

\section{Literature: EdUCATING FOR JUSTICE AND PEACE}

What pedagogical practices are a part of education for justice, peace, and ecological well-being? We addressed this question in a periodical review of three major

\footnotetext{
${ }^{1}$ We co-taught this course - the subject of our case study - at Candler School of Theology, Emory University. We thank the Wabash Center for Teaching and Learning Theology and Religion for generous support of the course and the Oral History Project, projects of Candler's Women in Theology and Ministry.
} 
religious education journals over the past ten years: Journal of Religious Education, British Journal of Religious Education, and Religious Education. ${ }^{2}$ The review has allowed us to probe the current dialogue in religious education and to flip the question Anne Wimberly (2003) asked in her 2002 APRRE presidential address: "What kinds of exercises of power in relationships militate against the relational qualities of justice, kindness, humility, love, and peace in our own institutions, in our communities, in our nation, and in our world?" (284-85). To pursue our research question thoroughly, we scanned every abstract (or article when abstract was unavailable). Selecting all articles that touched on education for justice and peace, we then proceeded to thematic analysis.

Contrary to earlier work in moral education by John Wilson and others, many scholars writing today emphasize that rationalism does not guarantee change. As Michael Grimmitt (1994) articulates, "it cannot be assumed that the dissemination of information about, for example, the religious beliefs and cultural values of ethnic minorities will, in itself, counter and modify attitudes of racial prejudice or inhibit racist behavior on the part of others" (137-38). Thus, we cannot simply teach students about justice and peace; we must also change how we teach (cf. Bellett, 1998). This claim is underscored by bell hooks (1994), who argues that "different, more radical subject matter does not create a liberatory pedagogy." Hooks carries the point even further, suggesting that "a simple practice like including personal experience may be more constructively challenging than simply changing the curriculum"(148).

Such discussions occupy much space in the current religious education dialogue, especially if we consider both implicit and explicit approaches to teaching justice and peace. Consider, for example, the work on inclusivity and human relationships. In discussing how to teach toward gender and ethnic inclusivity, Gayle Felton (1996) asserts, "Prejudice, bigotry, discrimination, and superiority are learned attitudes and behavior. Children absorb them through the conscious or unconscious teaching of others in home, school, peer group, popular culture, and religious communities" (154). Felton's argument that people learn negative behavior suggests, by extension, that people can also learn positive attitudes, such as respect, mutuality, inclusivity, and empathy. In this vein, Mary Elizabeth Moore (1995a) claims that respectful human relationships "undergird the justice and peace of the world" (224). Indeed, as we will see in this literature review, many religious educators have considered how to promote respectful human relationship through religious education.

Religious educators also raise questions of transcendence in teaching for justice and peace. In discussing values and virtues education in Australian schools, Pat Reiher (1999) reminds us that the religious educator does not act alone in helping students acquire human virtues through education and "deliberate acts." "Grace has an important role to play in the acquisition and maintenance of the human virtues and in the

\footnotetext{
${ }^{2}$ Due to limited availability of the Journal of Religious Education, we reviewed only the following volumes: vol. 47, nos. 1, 2, 4; vol. 48, no. 2; vol. 49, nos. 1-4; vol. 50, no. 4; vol. 51, no. 2; vol. 52, nos. 3, 4; vol. 53, no. 1. In the British Journal of Religious Education, we reviewed issues from Spring 1994 through Spring 2005. In Religious Education, we reviewed issues from Winter 1995 through Spring 2005.
} 
development of the virtuous person" (11). This reminds us that, while education can indeed support justice and peace, the task is not solely ours to accomplish.

In selecting articles for thematic analysis, we have erred on the side of inclusion, especially as concerns two genres of literature. First, we have included articles focused implicitly on justice and peace, such as studies of education for: values and virtues (Reiher, 1999; Kung, 1995; Ingall, 1998; Arweck and Nesbitt, 2004); liberation (Bellett, 1998); human rights (Gearon, 2002; Kung, 1995); great souled-persons (McArdle, 2001); and spiritual approaches to social justice (Yob, 1995). We have also included a second genre of literature that reports on oral history and life history-based research. For example, Lorna Bowman (1996) used oral history to research Holy Child Education in Nigeria and Ghana, and Pat Sikes and Judith Everington (2001) conducted life history interviews to study the experience of teachers in England and Wales. While these authors focused on different research questions from ours, we studied their work to glean insight on oral history as a teaching methodology in teaching for justice and peace. With this background, we can now turn to themes that emerge in the literature review.

\section{ENCOUNTERING DIFFERENCE: MIRROR, WINDOW, AND CONVERSATIONS}

One major question in education for justice and peace is how to assist students in encountering difference in positive ways. Indeed, some approaches to difference may lead to violence and injustice. Educators have approached the difference question in diverse ways. Susanna Hookway (2002) offers a helpful schema to organize some of these ways, describing education as: mirror, window, and conversation. Whereas Hookway's focus is on religious education with the millennial generation, many religious education researchers accent similar approaches to difference.

Mirror. For Hookway, religious education as mirror is coming to know oneself and one's values, beliefs, and cultural influences. Other researchers describe this mirror approach in diverse ways: making explicit students' pre-understandings (Streib, 1998); creating occasions for students to name their experiences in the world and the themes of their existence (Foster, 1997); knowing our own religious tradition (Brelsford, 1995); giving attention to our own biases and emotions (Moore, 1995a); increasing consciousness of our own perspectives (Grimmitt, 1994); starting with students' realities to achieve conscientization (Bellett, 1998); and the need for historical and political critical consciousness (Gearon, 2002). Such learning can be transformative in many directions. In discussing how to foster transformative learning in relation to spirituality, Stuart Sellar (2004) writes, "The way into transformative learning about spirituality, then is to start with reflection on our own experience ... So, reason and ideas are not overlooked, rather, we let our grass-roots experience lead us to mystery" (32).

The sheer number of authors who deal with this theme suggests that knowing oneself and one's environment is crucial to engaging difference. Norma Cook Everist (2001) suggests two reasons. First, beginning where participants are and using their lived experiences as material on which to reflect is non-coercive, non-violent. Second, 
knowledge of the self, when paired with encounters with difference, helps people avoid the unwitting projection of their own views onto others.

Window. Hookway uses the idea of religious education as window to describe coming to know someone or something that is different from oneself or one's lived experience. For Ted Brelsford (1995), learning from others can be transformative, yet it requires taking others seriously, being open to the potential for change, and having a certain level of trust. Some of this discussion in the literature takes on the language of encounter-how encountering another changes us. As Margaret Ann Crain and Jack Seymour (1996) describe their interviews with people who do ethnographic research, they find that interviewers and interviewees, ethnographers and the people studied, are all changed in the encounter. Susan Laird (1995) lifts up the example of Jane Addams as well. Addams recognized in her settlement-house work with immigrants that "education for and by such encounters could be crucial to foster the possibility of religious freedom and diversity witho ut violent intolerance" (125). Gayle Felton (1996), in considering how to teach toward gender and ethnic inclusivity, makes a similar observation: “"

Personal experiences with persons of different gender, socio-economic background, and ethnic heritage are essential in building relationships of respect. Such experiences need to include opportunities to interact with persons in situations which counter popular expectations of roles, open possibilities for reciprocity, and encourage mutual sharing (158).

This sort of personal encounter is one of the gifts that oral history can provide.

Fiction is another possibility for encountering difference. Heinz Streib (1998) suggests that a hermeneutic of fiction nurtures one's consciousness of difference. Fiction helps people get beyond rational explanation and immediate understanding because it refers to particulars but leaves open the possibility that things could be otherwise. For Streib, after the first step of "bringing to expression the everyday stories and everyday myths of the students," the second step of religious education is to help student invent a continuation of their story or rewrite it from a different perspective (329). Thus, encounters with difference are fostered through fiction and imagination.

Whereas some religious educators would advocate beginning with the mirror, with self-understanding, Shelley Barlow (2000) draws on the work of Emmanuel Levinas to argue that a just society will only happen when we ask, "Who is my neighbor?" and give priority to the other. As stated above, rationalism will not lead us to a just society, but face to face encounters with the other might do so, especially since the other draws us out of ourselves. Mitchell Gordon (1995) argues that educating South African students in diverse religious traditions may help with racism, for example, since race and religion are often linked. Similarly, Evelina Orteza y Miranda (1994) believes tolerance of people with different religious backgrounds will only happen when we teach about all religions in their particularity.

In contrast to Barlow, Eileen Bellett (1998) believes that education for liberation should hold conscientization (mirror) and critical solidarity with others (window) together as mutual movements in education. Discussing the need for inter-faith dialogue 
in schools, Karl Nipkow (1999) also advocates for balancing the mirror and window. He concludes that students need to have education in their own religious tradition and in inter-faith perspectives.

Conversation. Hookway's third category for religious education is conversation, which is about meaningful dialogue between two parties, a dialogue in which both parties are opened to being changed by the encounter. In discussing how to teach Christian particularity in a pluralistic world, Mary Elizabeth Moore (1995b) similarly proposes education by conversation - "seeking to know ourselves and others by engaging with the diverse traditions of Christianity and with the diverse traditions of other religious communities" (72). This suggests that people need more than to know themselves and others; these two realities must be put in conversation with one another.

A particularly compelling example of conversation in the classroom is Kevin O'Grady's (2003) ethnographic and action research on year eight religious education students in England, seeking to understand their motivations. O'Grady promoted conversation on three levels. First, he opened conversation between himself as teacher and the students, asking them to record in their journals questions they had about the topic at hand and their evaluations of different learning activities, then taking their questions and evaluations seriously in lesson planning. This also fostered conversation between the subject, which was Islam, and students' experiences. The unit on Islam thus began with questions of most interest to the students, such as Muslim dress. Finally, students were invited into conversation with one another through small group work.

\section{FOSTERING IMAGINATION, EMPATHY, AND WONDER}

Religious education researchers also consider how to foster imagination, empathy, and wonder through religious education. These qualities are implicitly related to education for justice and peace in a number of ways. For example, Reijo Heinonen (1995) links imagination and global responsibility, arguing that imagination is important for value-based decision making and for counterbalance to instrumental thinking, which has led to the north-south gap, increasing inequality between rich and poor, and unbalanced relationship s between humanity and nature. To overcome these problems, Heinonen encourages a new way to look at the world, one that includes imagination.

Both wonder and empathy seem to be pre-conditions for genuine encounters with difference. Kate Siejk (1995) names wonder as "the creative condition for religious dialogue," emphasizing that wonder helps us recognize that the other has something to say, that we may be changed by what is said, and that respect and openness to change are demanded by true dialogue. She notes the importance of a contemplative attitude to balance fidelity to our own values with openness to the other. Like Heinonen, she calls for pedagogies that recognize the importance of imagination. Similarly, Jeff Astley (1994) discusses the importance of empathy for imaginative comprehension of another's viewpoint, and Anabel Proffitt (1998) emphasizes how experiences of wonder promote reverence, epistemological humility, and appreciation. She adds, "We are confronted 
with otherness, and in wonder we allow that otherness to be, and do not attempt to incorporate it into our existing categories of explanation" (108).

While wonder and empathy are important pre-conditions for peaceful and just encounters across difference, they can also be the result of such encounters. Edward Everding and Lucinda Huffaker (1998) describe how human encounters with difference encourage the development of empathy. They write, "Broadening people's range of experiences through multicultural, intergenerational, or interreligious encounters provides information that fosters empathy to replace indifference or antipathy" (425). While encounters with difference may promote imagination, empathy, and wonder, religious educators name a number of other strategies for fostering these attitudes as well.

As mentioned above, Heinz Streib (1998) considers the use of fiction as an important way to invoke imagination and empathy. In considering the religious educator as a storyteller, Streib highlights the importance of lifting up small narratives:

Religious education should engage especially in remembering particular events and people who have names; or to rewrite the stories by referring to particularity and to names... Small narratives and small life-world narratives should be honored and held up over against meta- narratives" (330).

This is precisely what oral history does - attend ing to the particular stories of individuals in all their complexity. Similarly, Jan Grajczonek (2001) also advocates for the use of fiction in religious education as a way to reach the sacramental imaginations of young children in a language they can understand.

Two other authors highlight the power of poetry to open us to imagination, empathy, and wonder. Mary Elizabeth Moore (1998) understands poetry as "created on bridges between contrasting realities" (269). Poetry focuses our attention on relationships and connects us with the "rawness and depth of life" and with Divine reality (Moore, 1998, 274). Ross Keating (2004) has a similar respect for the power of poetry, emphasizing how poetry captures the play of the spirit in human life and opens students to experiences of wonder, contemplation, and insight.

In a similar vein, Susan Willhauck (1996) speaks of the power of faith language and liturgical practice to challenge our assumptions about what is, thus leading us into imaginative spaces of what might be and what we might do to reach this reality. Joyce Miller (2003) emphasizes the role of visual arts in religious education in stimulating and developing imagination and empathy. She writes, "Empathy and imagination are the means whereby religious stories can be entered into, by which pupils visualize events, places, and experiences, by which they respond to symbolism and the arts and which enables them to draw their learning into a coherent whole" (210-11).

At the conclusion of this section, let us pause to imagine religious education that includes fiction, poetry, liturgy, visual arts, and oral histories in a curriculum that undergirds justice and peace by opening us to new realities, to the Divine in our presence, and to respectful encounter with others. 


\section{Evoking Environmental Awareness ANd CoSMological CRITIQUe}

A third theme of the literature review centers on ecological education. While ecological education is not explicitly named in our meeting's theme of religious education for peace and justice, it is included here for two reasons. First, as Ruth Conway and Brenda Watson (1998) articulate, ecological justice and social justice go together. Second, three of the authors who attend to ecological education call for new cosmologies and anthropologies that are no longer anthropocentric (McArdle, 2001; Chamberlain, 2000; and Treston, 2001). They present cosmological and anthropological visions that could undergird education for justice and peace. For example, Kevin Treston (2001) names implications of a creation-centered religious education: (1) an anthropology where human beings are understood as part of the web of creation; (2) relationships that are egalitarian instead of hierarchical; (3) ethics based in earth care and justice (emerging from principles of "reverence for life, interdependence of all creatures, human stewardship, giftedness of life and ecosystem sustainability"); and (4) affirmation of dignity for all, equal rights, and the common good (7). Similarly, Patrick McArdle (2001) and Gary Chamberlain (2000) emphasize a relational anthropology grounded in accounts of creation.

One more dynamic of the literature on environmental awareness and cosmological critique bears mentioning. One of the primary ways that these authors promote ecological education is through sensitization to the issues. Conway and Watson (1998) urge educators to reflect on the purpose of technology and to educate with passion for nature and social justice. Karl Nipkow (1999) writes, "Sensitizing pupils to ecological issues in order to promote a different day-to-day lifestyle is a first step for schools to take, and one which needs to invoke the help of a number of different subjects, not only RE" (32).

While raising students' consciousness of ecological issues is important, simple changes in the content of religious education will not be enough to promote peaceful and just interactions with the created world. We also need to envision ways of teaching, and patterns of interaction in educational settings, that support ecological well-being.

\section{UNMASKING VIOLENCE}

A fourth theme in the periodicals is unmasking violence. An excellent example of this concern is Ilan Gur-Ze'ev's (2000) article on the link between Holocaust education in Israel and the Israeli/Arab conflict. Gur-Ze'ev emphasizes how Jewish-Israeli identity is linked to a particular version of the Holocaust memory, which claims that Jews are the true sufferers, to the neglect of recognizing the suffering of others who have faced genocide during the twentieth century. Advocating for sensitivity education that recognizes all genocides, he writes,

This is the only way to save Judaism in Israel from the dogmatism and violent institutionalism which has resulted from its barbarization. The teaching of the miseries of other people and education for empathy is not only an alternative to the anti-Judaic orientation of the hegemonic Zionist ideology, it also represents a resistance to and refusal of the current Israeli instrumentalist-egoistic and ethnocentric interpretations of Judaism and its educational implications (382). 
Gur-Ze'ev's point is that Holocaust education, as currently conceived in Israel, leads to a lack of care for other sufferers and a violent approach to those who are identified as others and enemies. Thus, an important step in unmasking violence is to examine our curriculum for how it perpetuates violence and injustice. This is precisely the first step that Russell Moy (2000) suggests for religious educators to undertake in an effort to counteract the racism that has often been a null curriculum in the field.

A second element of unmasking violence is paying attention to the language we use. Discussing teaching toward gender and ethnic inclusivity, Gayle Felton (1996) insists that language is an important tool for working against racism and sexism because language shapes the way we think. Extrapolating from this, we may also conclude that we need language centered in peace, justice, and ecological well-being if we wish to overcome violence, injustice, and ecological degradation. To this end, we need to be aware of how we use a language of violence. To cite a negative example, Peter Elliott (1999) describes the position of the Christian church in our time as "involved in a culture war" (19). In fairness to Elliott, he does explicate how he understands the term culture war in less than violent terms, writing, "A culture war should never be pictured as the Christian citadel under siege, or worse, a ghetto under attack. A more plausible model would be a free-market of competing and conflicting ideas, but with the stakes and goals that are personal, supernatural and eschatological" (22). He also emphasizes that Christian apologetics should avoid aggressive confrontation. Despite all this, Elliott still insists on framing the Christianity-culture relationship as war, which in commonsense terms, connotes violence and the necessity that one side win out over the other.

\section{CONNECTING EDUCATION WITH THE "REAL WORLD"}

A final theme that arose in the periodical review was the importance of connecting education for justice, peace, and ecological well-being with the real lived experiences of students. Carol Ingall's (1998) ethnographic study of a Jewish day school offers a paradigmatic example of the effectiveness of contextualizing curriculum for the good of a community. Two goals of the day school were to foster Jews with critical minds and compassionate hearts and to stop dividing the "real world" from Judaism, as felt by many of students. To address these go als, the teachers created their own curriculum on Jewish values, choosing a monthly theme to cross curricular areas. The school's identity as a caring community was fostered by this home-grown curriculum, which met student needs and supported the school's overall vision as a moral community.

Service in the community is another means for connecting education with the "real world." After investigating the history of the term solidarity, Michael Kelly (1998) recommends that grounding education in metaphors of connection and giving students experiences of connection through service may promote their solidarity with those who are oppressed. Additionally, he encourages religious educators to remember and re-tell stories of disconnection: "These stories disturb consciousness and counter the perennial tendency to forget that both individuals and groups pay the costs of systems that benefit the majority" (Kelly, 1998, 62). Similar emphases are developed in the extended case study of St. Francis High School in Youniss and Yates (1997). 
Other ways that educators advocate connecting education with lived experience include: urging those in the church to speak the language of the public as well as the language of faith (Willhauck, 1996); using action research's cycle of observing, reflecting, planning, and acting to study our own religious communities to facilitate improvement and involvement (Martin, 2000); and inviting people to reflect on their lives of faith and to engage in theological reflection at their workplaces (Everist, 2001).

\section{CONCLUSION}

This review uncovers few articles that address the specific topic of teaching for justice, peace, and ecological well-being. Our hope is that the focus on religious education for peace and justice at this year's annual meeting will begin to remedy this situation. Our further hope is that future literature reviews will consider books as well as articles, thus providing a more comprehensive perspective on education for justice and peace. Until then, the essays reviewed here offer extraordinary insight.

\section{CASE S TUdy: Teaching THROUgh ORAL History}

The literature, as we have seen, addresses questions of how and why to teach for justice and peace. Implicitly, the same literature raises our research question: how and why to cultivate a spirit for justice and peace in teaching across a religious or theological curriculum. One key phrase in our research question is "spirit for justice and peace." By this we mean an embodied attitude or passion for just and peaceful relations with the human community and natural world, which permeates a person's or community's ways of being and acting in the world. The other key word is "to cultivate." By this we mean giving students opportunities to explore the spirit of justice and peace in their ways of engaging with others in the classroom, reflecting on the subject matter, experimenting with careful attending to others' life stories, and drawing wisdom from many sources (living and dead) for the construction of religious educational theory and practice. Qualities identified in the analysis of literature suggest many possibilities for cultivating such a spirit. We hope to discover others in analyzing the Prophetic Pioneers in Religious Education class. We thus begin with a brief description, followed by a multi-faceted analysis, which allows us finally to draw wisdom from the case about cultivating a spirit for justice and peace.

\section{CASE INTRODUCTION}

As described in the introduction, the purpose of "Prophetic Pioneers in Religious Education" was to "explore religious education history, issues, and visions through life story, contextual analysis, and educational theories, practices, and cultural "products.", We did this through a series of topics and assignments that were related to these topics. 
(1) Introduction: Reflecting on the students' histories and perspectives on religious education, as well as movements in the history of religious education and the ways in which prophetic pioneers helped to shape the se movements

(2) Exemplars : Reflecting on the lives and work of prophetic pioneers, including Paulo Freire (Pedagogy of Hope: Reliving Pedagogy of the Oppressed) and a few of the women pioneers in Christian religious education (as collected in the Christian Educators of the 20th Century project at Talbot School of Theology). We approached these texts with such questions as: (a) How does this text address you; (b) what were the person's central educational commitments, and how were these intertwined with the person's life journey and social context; (c) how do you evaluate the person's contribution; (d) what do you learn from the person about human existence, Christian vocation, and religious education theory and practice; and (e) what visions of religious education are stirred for you by this study. Class discussions of the exemplars involved some dramatization of the readings and role playing with the characters as well.

(3) Art of Oral History: Reflecting on the purposes and values of oral history, informed by Elaine Lawless's Holy Women: Wholly Women; and reflecting on oral history methods and preparation, informed by Donald A. Ritchie's Doing Oral History. Students also completed an Institutional Review Board certification so as to be qualified to conduct research with living subjects-a requirement of Emory University even when research is done within a class context.

(4) Discovering Educational Wisdom through Oral History: Reading and reflecting on the remaining women's biographies in the Christian Educators of the $20^{\text {th }}$ Century project, focusing especially on the educational wisdom that emerges from their stories. Another assignment related to this topic was a portrait paper, in which students were asked to write about a prophetic pioneer (5-7 pages on one of the people we read or someone else of their choosing). The papers included: (a) description of the person's life, context, and religious education work; (b) critical evaluation of the person's contributions; and (c) the student's projections for religious education in light on this person's influence. Some people focused on figures about whom we had read in the texts; some used oral histories that we had collected earlier and held in Candler's religious education resource center; and some interviewed people whom they knew.

(5) Human Values of Oral History: Readings from books that focused on the values implicit in oral history and the use of oral history to elicit values in their embodied, existential forms. These included: Sherna Berger Gluck and Daphne Patai, eds., Women's Words (two chapters); Alan Wieder's Voices from Capetown Classrooms (students each receiving two chapters to "teach" to the class); Diane Tickton Shuster, Jewish Lives, Jewish Learning (four chapters).

(6) Oral History Preparation and Intervieus: Studying background information on the three persons whom we were to interview. Each of three groups prepared one interview; developed a method for approaching the interview and an introduction to the person (based on the group's research); read background materials by and about all three interviewees (selected by the lead group for each interview); participated in class as host-interviewers on the day of their interview, and as a group of avid listeners on the day when other groups were interviewing. 


\section{Pedagogical Commitments and Practices}

To be honest in presenting this case, we begin by acknowledging our pedagogical commitments, or assumptions. These commitments permeated the course construction, and they were elaborated and refined as the course unfolded. Interestingly, Mary Elizabeth had identified all of these commitments before drafting the syllabus, and Claire discovered the commitments in analyzing the class plans and class session notes. The six commitments are enumerated separately for conceptual clarity, but they flowed into each other. The teaching team embodied these commitments, more and less effectively, throughout the semester:

(1) Teaching in a method that is faithful to the author and/ or the subject. One goal was to match content with pedagogical practice. For example, as a gathering ritual the day we began discussing Freire's Pedagogy of Hope, we asked students to read a quotation from the book that spoke to them, reinforcing Freire's notion of reading that makes a difference. Another example came when we delved into Elaine Lawless's Holy Women, Wholly Women. Since this book stems from Lawless's reciprocal ethnographic research with women clergy, we asked students to present the stories of the women in the book through interview format; that is, in small groups the students did mock-interviews with one of the women. They then presented the mock-interview to the entire class as a way to bring the lives of Lawless's subjects into our midst for further discussion and analysis.

One of our underlying aims was to teach as much as possible in a way that was true to the methodology of oral history. Elements of this included: privileging stories and affirming that every story communicates some truth and that the larger body of truths can be found in negotiating multiple stories; practicing hospitality grounded in deep respect for the personhood of one's self and others; seeking to understand our own locations so as to be more flexible and open when encountering stories of others; and developing skills for empathetic and active listening, careful questioning, and insightful analysis.

(2) Privileging stories and attending to our own stories and contexts. The course quite literally began, peaked, and ended with stories. The gathering ritual of the opening session invited students to share stories of a personal, previous experience with religious education. The focal point around which much of the course revolved were the interviews with three living women prophetic pioneers in religious education, and the ir sharing of their life stories toward the end of the term was a true gift to the class. The final session, a festival of wisdom and vision, involved students sharing portions of their final projects. Interestingly, many of the students' projects and visions for religious education directly flowed from their own experiences and included further telling of their own stories.

Along the way, we were treated to the life stories of prophetic pioneers of religious education, both past and present, as well as stories from the Bible and stories about the lives of communities. Consistently, stories came first, and only later would analysis follow. Throughout the semester, students were invited to write about, meditate on, and articulate their own stories in relation to session 
topics, bringing that narrative consciousness to bear on the subject at hand. The stories were not only for conscientization, however; stories were also used to build the learning community and to learn from the diversity in our midst.

(3) Taking on the voices of others in an effort to understand their stories, work, and positive contributions. Embodying the figures we studied took many forms, one of which was dramatization. For instance, small groups of students were assigned pieces of Freire's work and were asked to present dramatically the main themes from the assigned piece. Another form this embodiment took was asking students to become one of the figures we encountered. For example, we asked students to take the role of Freire and to name, from his perspective, what they wanted people to have gained from interacting with his work. Another example is when we asked students to take on the persona of a woman pioneer whose biography they had read. We asked them to imagine themselves in a conference of religious educators where the main topics of discussion were educational commitments and visions for the future of religious education. They participated in the simulated conference as if they were one of the pioneers.

An important note here is that the role-taking exercises did not preclude critical engagement with the life stories and texts. On the other hand, we always engaged empathetically prior to the more critical movement; that is, we attempted to understand each life story and text on its own merits and using its own logic before posing challenges to it. For example, after students shed the roles of women pioneers in our mock conference, we evaluated their contributions to the field of religious education.

(4) Going back to our sources and our guiding questions more than once to attend more fully to our subjects and to deepen our learning. In a sense, we never left anything behind in this course. The assignments and readings flowed into one another, as in our encouragement for students to let the portrait and methods papers influence the ir final papers. Part of what made this possible was our consistent use of the five focus questions (\#2 in Case Introductionabove). Thus, we were able in the final weeks to discuss what we had learned about human existence, religious education, and vocation from the women we interviewed, while making comparisons and connections between what these women said and what we had read earlier. This deepened our reflections at the end of the semester, as we were able to consider all of the voices.

Another common practice was to return to texts in more than one class session, thus enabling us to dig deeper into each text. Students, for example, read the bio graphies of two women pioneers early in the course; three weeks later they read the entire anthology. Our discussion in both class sessions centered on the focus questions; thus our second discussion was more nuanced. We were able to appreciate the women's lives and critique them more fully.

(5) Developing guidelines for oral history and building skills for the interviews with prophetic pioneers in religious education and skills for future ministry. One central activity of the class was developing, as an entire class and in conversation with a number of texts, a list of guidelines for doing oral history. We added to and refined the list over a number of weeks, both in class and in one case outside of class over e-mail. Our work on this set of guidelines began the fourth 
week of class in relation to Lawless's Holy Women, Wholly Women (1994), took into account what we learned through the Institutional Review Board certification process, was expanded in conversation with Donald Ritchie's Doing Oral History (2003), and was eventually personalized by each interview group to fit the purposes of their particular interview and interview team.

In addition to developing class guidelines for doing oral history, we worked from the first class session to develop skills that would serve us in conducting and analyzing the interviews. In the first session, we watched a video oral history interview with Olivia Pearl Stokes and began to practice our analysis with that interview. We returned to a more specified form of analysis, derived from the ethogenic method, later in the class to uncover the patterns of interaction and salient themes in the community-based oral history of the New Town Florist Club. In the second class session, students began practicing the art of interviewing with one another, and they had multiple chances through the rest of the term to be interviewer, interviewee, and participant observer. As the semester progressed, students spent more class time in their interview groups, focusing on activities such as identifying primary purposes for interview, choosing texts for the rest of the class to read, developing their interview questions and protocol, writing their group methods paper, and finally, conducting the interviews themselves.

We invested time in these practices because we believed that skills of attentive listening, insightful questioning, respect, and hospitality, which are necessary for oral history, are also valuable for teaching and ministry. We practiced these skills each class session through table fellowship, respectful engagement with one another, and lively discussions, in addition to mock interviews. These practices culminated in the final interviews and analyses.

(6) Exposing ourselves to a diverse peoples and pedagogical experiences. Readings were one way that students engaged diverse peoples. We read of Freire's educational endeavors with Brazilian peasants, Elaine Lawless's reciprocal ethnographic work with women ministers, life stories of women pioneers in religious education, Diane Tickton Schuster's interviews on Jewish education, and Alan Weider's collected stories of South African educators during apartheid. We also exposed students to the diversity of our class, using both large group discussions and small group projects to engage students with one another.

An additional, intentional layer of diversity in the class was the use of diverse pedagogical practices. We employed such methods as: video viewing; lecture; large group discussion; group work on guidelines for oral history; small group work to teach a selection of readings to the class, to reflect on student writing, and to plan and implement an oral history interview; work in pairs to share stories and begin analysis; silent reflection; journaling; rituals of prayer including embodied prayer; role playing and dramatization; and a festival of wisdom. Diversity of content and process were thus woven through the course.

\section{Communication Practices}

We also undertook a thematic analysis of the class's e-mail communication. Over the course of the semester, we saved thirty-eight e-mails and sent (but did not save) 
approximately twenty more to non-class members to arrange details related to the class. Of the e-mails that were saved, over half (20/38) were sent by the professor or the teaching assistant to the entire class or project groups. Only four of the saved e-mails were from individual students to the professor, and one e-mail was from a student to the entire class. While e-mail mainly was used to disseminate important reminders and details about the class and to share personal questions and needs, it is notable that so few students used e-mail to contact the professor regarding ideas and the class' common work or to share information with the entire class. If our goal is to promote just and peaceful education, we may wish ask whether e-mail becomes just one more way professors exist in a hierarchical relationship with their students.

Our analysis of the saved e-mails yielded six purposes of e-mail communication in the learning community: (1) reminding students about upcoming class sessions, including information about what to bring to class and reminders about focus questions for the week's reading; (2) providing information updates, including appraising students of the status of the potential prophetic pioneers to be interviewed; (3) distributing additional course materials, such as biographical information on interviewees and the final grading scale for the course; (4) offering feedback for students, particularly on their group method papers and interviews so that everyone in the group could receive a copy of the feedback; (5) encouraging and thanking students, with a focus on their good work in class discussions and in the interviews; and (6) raising concerns and asking clarification questions, which was the main way that students used e-mail.

As is evident from this list of purposes, much of our e-mail discourse consisted of practical planning for the course. That so many of our e-mails were related to the practical planning of the course seems to correlate with the collaborative oral history methodology. At the beginning, students were expected to participate in shaping the course, so the finalized syllabus was not distributed until the second week (the first week being a time to consult with the class, using a syllabus with full introductory material, but an incomplete class schedule). As the course unfolded, the teaching team provided supports (suggestions and information) to prepare students for the oral history disciplines, and for their planning and implementation. We also encouraged them to communicate with us about their questions and concerns.

In addition to the six purposes identified in course communication, two main content conversations took place over e-mail. The first was about the prophetic pioneers who were nominated to be interviewed for the Oral History Project, including their professional information and reminders that the three women represented: different Christian traditions; diverse ministry experiences, ethnicities and backgrounds; and people who are typically underrepresented in historical studies of religious education. The second content conversation occurred when a student used e-mail to respond more fully respond to a question that Mary Elizabeth Moore had addressed to him in class. She had responded to his general comment by inviting him to convert it to a positive and concrete guideline(s) for oral history. The student pondered the question, sent a response by e-mail and gave permission for Mary Elizabeth to forward his message to the class, thus supplementing the class-developed guidelines for oral history. 
This student was one of five (in a total of twelve students) for whom English is a second or third language. In the early weeks of the semester, the student seemed to find email communication easier than oral dialogue in class. This incident suggests that, for students taking course work in a second language or preferring written expression over oral, e-mail and other forms of technology may prove liberative.

\section{STUDENT PERCEPTIONS}

Another area of course analysis focused on student perceptions of the course. During the final class session, students were asked to complete an evaluation. The standard form includes a number statements about the course to which the students responded using a Likert scale, as well as some open-ended questions to which the students responded about whether they would recommend the course to other students, their reason for taking the course, the major strengths of the course and the instructor, the major weaknesses of the course and the instructor, whether the course met or exceeded expectations, which readings were especially useful and why, and how the instructor can improve this course. To insure that students felt safe to provide honest feedback, they completed the forms anonymously, and one student returned them to the registrar. The forms were not available to the teaching team until we submitted final courses grades.

Two statements on the evaluation forms seem particularly relevant for evaluating oral history pedagogy to cultivate a spirit for justice and peace. First, in response to the statement, "This course helped me to appreciate and learn from views different from my own," six students strongly agreed and six students agreed. Second, in response to the statement, "This course has encouraged respect for and engagement with matters of face, gender, and class," eight students strongly agreed, and four students agreed. At least according to these measures, all students agreed to a relatively strong degree that this course promoted respectful engagement with difference.

To analyze the open-ended questions, we first made a list of words used in student responses, tallying words and phrase. We then grouped like words and phrases into clusters of ideas, indicating what students experienced in the course. We calculated the number of occurrences for each cluster to see how strongly each cluster was perceived by the class as a whole. The following are the clusters we identified and their relative weight (count in parentheses).

Students in "Prophetic Pioneers in Religious Education" experienced...

(1) Developing pedagogical awareness (44). In evaluating the course, students used a multitude of words and phrases to express their awareness of attention to pedagogy, particularly the use of oral history as a methodology for teaching. The most common terms in this cluster were religious education and learning, but other relevant words and phrases were methods, blending (of spiritual practices and reflection with academic learning), design of the course, various class activities, and different paradigm. One student, in naming whether the course 
exceeded expectations, wrote that the unexpected pedagogy of the class and the diverse learning activities used ended up being enjoyable.

(2) Practical knowing (44). Here students used words such as insightful, interesting, effective, relevance, concrete, informative, and useful, indicating a sense that the knowledge gained through the class would have practical implications for their future educational work and their vocations. For example, in naming the strengths of the course, one student commented, "The oral history project was a great exercise and experience for my future work in this field."

(3) Positive learning (38). Eleven students answered the question of whether the course had met or exceeded their expectations in the affirmative (the twelfth student did not complete the second side of the evaluation form where this question was located). Other words and phrases used to indicate a positive learning experience in the class include enjoyed, keep it up, engaging, and no notable weakness. As one student put it, "The course was designed in a manner that was democratic, engaging, informative, and challenging."

(4) Encountering cultural and pedagogical diversity (36). Five of the twelve students commented on the diverse material covered in the course or the various class activities that were employed to explore this material. As highlighted in item $\# 1$, there was also mention of being exposed to different views (for example, to Jewish and South African educators) and different paradigms for education. In commenting on the strengths of the class, one student named "lots of discussion that helped with different views from many different cultural perspectives."

(5) Active learning (34). Students used many active verbs to describe their experience in the class, such as discover, explore, read, think, question, share, search, and interview. One student wrote, "When I looked at the syllabus I initially felt it may be too much work for the timeframe. However, it was so engaging that the assignments naturally flowed from our reading."

(6) Engaging with prophetic pioneers (33). Given the title of the course and its central subject matter, that students experienced interactions with prophetic pioneers is not a surprise. Students wrote both of prophetic pioneers in general and mentioned specific prophetic pioneers whom we studied who were particularly influential for the students. They recognized prophetic pioneers as leaders, facilitators, innovators, educators, mentors, and professors. As one student noted, "we covered major prophetic pioneers, many whom I had never heard of."

(7) Forming learning community (30). Three students used the phrase "learning community" to describe their experience in the class, and other students used related words such as cooperative, sharing, and together. As one student remarked, "We worked and shared together. We built up this class as a learning community."

(8) Creating wisdom (27). Two students mentioned the creativity inherent in the course and the instructors' approach to the course, and four students made comments about the wisdom that was present in the course in the figures of the professor, the TA, and the other students. One student indicated that the class helped the student to project a creative vision for religious education. 
(9) Practicing hospitality (24). Three students referenced the kindness of the professor, three used the word open in relation to the professor, two wrote about how the professor encourages students, and two referenced how the professor motivates students. Other hospitality terms mentioned were affirming, comfortable, loving, available, and concern for students. In naming the instructor's strengths, one student affirmed that she is "very open, makes the students feel at ease and willing to contribute."

(10)Participating in experimental pedagogy/trial run (24). Five of the twelve students indicated that they experienced this course as a trial run through their comments about the weaknesses of the course and ways to improve the course in the future. (A different set of five students made no comment about the weaknesses of the course.) One student was troubled particularly by not knowing the weight of each assignment until near the end of the term because it made it difficult to calculate one's grade, and three students named the course as disorganized, noting how this affected the availability of texts for the course, the syllabus (which was incomplete when handed out at the first class session), and the interview groups (one of which had problems finalizing their interviewee, a problem they felt put them at "an unfair advantage."). In naming the weakness of the course, one student stressed that it "felt like we were making it up as we went along; I believe it will be better organized in the future as this was a trial run."

(11)Participating in oral histories (22). This is another cluster that is not surprising given the subject matter of the course. Three students referenced the oral history project, and two mentioned the interviews. Under additional comments, one student commented, "It was a great experience and helped to reform my idea of religious education and the value of oral history within education and communities."

(12)Meeting challenges (8). Four of the twelve students spoke of the challenging nature of the course, both in terms of the course design and in terms of the instructor challenging the students. Speaking of the professor, one student wrote that her strengths were "affirming and confirming people's strengths as well as challenging their respective pursuits."

(13)Ritualizing (6). Students referred to prayer, ritual, spiritual practices, and reflection to describe the ritual aspects of the class. Naming a strength of the professor, one student emphasized, "She always opens class by a variety of 'gathering rituals." "

\section{Discoveries in the Practice of Teaching Through Oral History}

To conclude the case study, we will identify conclusions that emerged in class discussions and presentations. These conclusions first emerged in the second to fourth weeks when the class identified the educational commitments of Paulo Freire and the women pioneers. Similar themes emerged throughout the semester, leading us to identify the following educatio nal values as central to the course:

- Focusing attention on those usually denied it, especially women and children. This educational value includes conscientization regarding the experience of 
marginalization, as well as advocating for and creating spaces for marginalized people in religious communities. In discussions, students recognized the commitment of Edna Baxter, Iris Cully, Mary LeBar, and Sophia Lyon Fahs to child-centered education, and they noted Dorothy Jean Furnish's commitment to helping women discern their vocations in the church. They also recognized the tendency of many women pioneers to break gender boundaries.

- Committing to making a difference in the world and persevering within oppressive systems despite obstacles. A second educational value is the importance of working to transform society and promote justice and peace through education. Hope is central to such transformative religious education. Students expressed repeatedly their admiration of religious educators such as Olivia Pearl Stokes, secular educators such as the South African educators in Capetown, and the ministers interviewed by Lawless, who followed their vocational calls and visions for ministry in the face of external obstacles. They also named Freire's and the Capetown teachers' emphases on the political nature of education; and they noticed that educators such as Eileen Egan and Olivia Pearl Stokes were committed to educating for justice and peace among diverse peoples.

- Attending to the contexts of our educational ministry, recognizing how we are shaped by our context, and respecting the contextual realities of those with whom we learn. The imperative here is for educators to learn about the realities of students so that we can begin from where learners are in their journeys. One of Olivia Pearl Stokes's commitments was to base religious education in people's experiences, and students noted how she stressed speaking others' language (but without compromising one's own integrity) in order to reach students. Students also noted Freire's accent on reading the world as well as reading texts.

- Educating the whole person at all ages for the whole week. This educational value included attention to "multiple intelligences." While many of the educators we studied would not have used this term, they knew the importance of using a variety of learning activities to meet the needs of a diverse group of learners. Coming out of engagement with Freire, students articulated that religious education should not be equated with filling others with knowledge but should be toward the goal of helping learners to construct knowledge. Students noted Edna Baxter and Adelaide Case's main commitments in religious education as connecting education with all areas of a person's life, thus not separating "Sunday" and religion from the rest of people' lived experiences. They also saw the commitment of many of these educators to developing innovative curriculum grounded in Christian belief and the Bible, as well as the arts, narratives, and human religious experience.

- Building bridges between science and religion, between traditionalism and progressivism, between cultures, between generations, between church and home, and between practice and theory. This educational value came to the fore on the first day when Olivia Pearl Stokes raised the metaphor of the educator as a bridge builder between gaps in understanding. Students also saw Taylor and June McConnell and Edna Baxter as committed to multicultural dialogue as a result of their travels abroad and, in the case of the McConnells, their living with Pueblo and Hispanic people in New Mexico. Another major bridge-building theme 
emerged in the live interviews, namely an emphasis on intergenerational conversations, as well as creating partnerships between communities of faiths and family life.

- Practicing hospitality and accepting those who are different as guests. This educational value focuses on respect for the humanity of all people. The importance of creating a welcoming learning environment was a particularly salient theme in our discussion of Schuster's Jewish Lives, Jewish Learning, as well as the three class interviews.

The class and teaching team also drew conclusions about oral history methodology. Some of these were preliminary assumptions, but all were modified and enlarged by the journey of the learning community. We found that oral history serves many purposes: (1) creates a forum for sharing emotion-laden stories; (2) values the lives of people in the background of their communities; (3) reveals the textures of social movements, often uncovering movements that are not widely recognized or sanctioned by the larger society; (4) creates a safe space for telling stories of terror and hurt, even opening space for healing; (5) raises consciousness about the plights of people whose lives are filled with terror; and (6) stirs imagination and courage for action in the future. These various functions of oral history represent the major values in the course on Prophetic Pioneers, partially shaped by the very subject of the class. Other functions also exist, but this short list reveals much of the power of oral history methods for cultivating a spirit for justice and peace.

Looking at the class discussions and the oral history values, we find important clues to guide education for justice and peace. One is the importance of valuing human life in our educational practice, especially valuing people who are undervalued in the larger society. Another is the value of giving people tools and opportunities to learn about and empathize with others, both as complex individuals and as part of complex social contexts. Education that embodies this value contributes to mutual respect, and creates opportunities for hospitality and healing. Still another value is the opportunity to study social phenomena - diverse communities, cultural contexts, and social movements - and to discern how these diverse social settings relate with one another and stir diverse intellectual or religious perspectives. Finally, a critical value for education is to inspire and equip people for action - to help people discern the aches of this world and to make a positive contribution to life.

\section{STEPPING B ACK AND STEPPING ForWARd FOR Justice AND PEACE}

Having engaged in an extensive analysis of literature and a case study, we need now to step back, bringing each analysis to bear on the other. To engage in this interpretive move, we have conducted a two-way dialogue, seeking clues that point forward toward justice and peace in the conceptualization and practice of religious education. We present these pedagogical themes as if they were discrete categories but, in reality, they intermingle. We anticipate that the Research Interest Group discussion will uncover still more pedagogical insights and other steps forward. This too is 
important if education for justice and peace is a truly mutual process. The fruit of all these themes will be clues for cultivating a spirit for justice and peace in the future.

\section{ENGAGING IN ACTIVE, PRACTICAL LEARNING}

One obvious pedagogical theme emerged from the literature and case study - the value of engaging people in active, practical learning. As the literature pointed to the urgency of education that connects with the "real world," so students in Prophetic Pioneers expressed appreciation for opportunities to search, explore, discover, question, interview, and engage with prophetic pioneers and other class members. Such comments reinforce the value of helping people construct knowledge. They also suggest the value of developing skills (as interviewing the three living pioneers) that equip people for their later work, especially skills of attending to others with respect, practicing hospitality, asking honest questions, and engaging in collaborative analysis and theory-construction. Such skills undergird respectful human relationships and enhance people's ability to contribute to the long process of building justice and peace in the world.

\section{ENCOUNTERING CULTURAL, CONTEXTUAL, AND PEDAGOGICAL DIV ERSITY}

A second pedagogical value for cultivating a spirit of justice and peace is to help people encounter cultural, contextual, and pedagogical diversity. This is a major theme in the literature, especially engaging learners with people different from themselves. This was a value of the course as well - not only an intentionally planned value, but also one that students emphasized in their evaluations. They appreciated the diversity represented in the class itself, in the readings, and in the three oral histories that we conducted. They frequently named new discoveries about social movements as well, as in the comment by two African American students that they had not realized the Shrine of the Black Madonna was so deeply Christian and such a powerful movement. Students appreciated more than the surface diversity, but also the richly textured stories that evoked sadness, anger, laughter, and inspiration, thus touching engaging them with people in their particularity and with the depths of human existence.

These insights resonate with the literature review, especially the values of encountering difference through the metaphorical mirror, window, and conversation. The class enacted the mirror from the first day, beginning with students' sharing stories of their religious education experience and reflecting frequently about how the prophetic pioneers addressed us. The class enacted the window through engaging with the prophetic pioneers, both in reading and in live interviews. And they enacted conversation in class discussions, including those discussions when they took on identities of those whose stories we had read. Even more fully, conversation took place in the small group interviews with living pioneers.

We conclude that education that cultivates a spirit for justice and peace requires more than pleasant moments of interacting with diversity. It requires intentionality in engaging peoples and contexts that are on the margins of social value, and efforts to discern the wisdom of each community or individual studied. It also requires 
opportunities to do contextual analysis and to investigate social conflict, whether in a particular community (such as the Shrine) or larger society (such as South Africa).

Further, it requires pedagogical diversity (a conclusion that was more visible in the case study than in the literature). Pedagogical diversity is a way to engage a learning community in multiple ways of knowing, thus evoking more complex and extensive learning.

The cultivation of justice and peace is both explicit and implicit in these comments. Not only does this analysis suggest the importance of encountering diversity, but it also suggests some particular values of oral history as an approach to religious education, both for explicit and implicit contributions to justice and peace. Oral history can till the soil for deeper and more respectful human relationships, can help people learn from other human lives and social movements, can help learners understand social conflict more complexly, can help people learn from those who have worked directly and indirectly for justice and peace, and can equip people with skills to build just and peaceful human interactions in the future.

\section{ENCOUNTERING THE DYNAMICS OF SOCIAL SYSTEMS}

The third pedagogical theme emerges naturally from the previous one, namely the value of encountering the dynamics of social systems. The literature review revealed that many who write about education for justice and peace adhere to Paulo Freire's adage that education is never neutral. Our work with oral history reinforced this adage as well. We repeatedly discovered how educators and teachers understood and contributed to the social systems in which they lived. We also discovered how they contributed to revolution in those systems, whether local religious communities, denominational structures, higher education, or other social systems. In some cases, their revolution was to advocate for children and to develop more adequate educational approaches for young people (as the work of Sophia Lyon Fahs, Dorothy Jean Furnish, and Lois and Mary LeBar). In others, the revolution was to provide leadership training and opportunities for people living on the margins of society (as Olivia Pearl Stokes' work with African American youth in the mid-twent ieth century and Anne Wimberly's work with homeless people in the 1980s). Through oral histories, a learning community can discover this revolutionary work of individuals, but not in isolation; the community simultaneously discovers the dynamic social systems in which the "revolutionaries" have lived.

What we discovered in our oral history pedagogy is the possibility of learning through life histories about the complexities of social movements and the interrelatedness of movements in the larger society. What is added from the literature is the importance for justice and peace of unmasking violence, evoking environmental awareness, and engaging in cosmological critique. This did indeed happen in the oral history approach, but only through the particular stories of people who engaged self-consciously with violence or environmental devastation in their contexts, as the teachers of Capetown in the era of apartheid or Mercedes Iannone who faced a quietly violent situation within her parish. For education to cultivates a spirit for justice and peace, oral history can be a 
valuable approach, but will need to be supplemented with other approaches to social analysis if the full complexity and terror of some social situations are to be revealed.

\section{BUILDING STRONG AND MULTIVALENT LEARNING COMMUNITY}

A fourth pedagogical theme is the importance of building a strong and multivalent learning community. This value was underscored in student evaluations of the Prophetic Pioneers course, particularly expressed in their appreciation for our common efforts to form community, practice hospitality, and engage in ritual practices. Students discovered similar values and practices in the prophetic pioneers whom we studied - pioneers who espoused and practiced community building, both in their local communities and in their international, ecumenical, and interracial work. Students also saw connections between these community-building efforts and the work of social and ecclesial reform; thus, they made indirect (and sometimes explicit and direct) connections between communitybuilding and the work of justice and peace. In our analysis of the class, we do have some questions about how we might build community with still more fullness, as in promoting more dialogical use of e-mail and other technological resources, such as Blackboard.

\section{FOSTERING IMAGINATION, WONDER, AND EMPATHY}

One of the major themes in the literature is the importance of fostering imagination, wonder, and empathy. This theme was an intentional part of the Prophetic Pioneers class as well. We consistently asked students to identify the educational visions of the pioneers we studied, as well as their own visions. Their emerging visions were, in fact, the heart of their final presentations and papers. We also tried to invoke imagination and empathy throughout the course, asking students to take on the roles of those about whom we read, and calling attention to some of the striking events in the stories that we (students, teaching team and interviewees) shared and read. These events, usually small in themselves, often had power to evoke empathy and wonder, even to evoke possibilities and hope for the future. In this way, the very process of imagining, wondering, and empathizing nourished a spirit for justice and peace.

\section{INSPIRING CREATIVE AGENCY}

Another pedagogical theme is also important to cultivating a spirit for justice and peace - inspiring creative agency. Students in Prophetic Pioneers named two experiences worth noting here: the importance of creative learning and constructing, and the value of participating in an experimental pedagogy. From these we learn how important it is to encourage a community to be creative in learning and constructing knowledge (including imagination and wonder as discussed above) and to be active in learning by doing (akin to John Dewey's emphasis on active and experimental pedagogy). As with other pedagogical themes, the class also found these values in the work of our prophetic pioneers, who frequently developed innovative (sometimes culturally subversive) curriculum and helped learners construct knowledge. Further, students discovered these values in the process of conducting oral histories. One student interviewed people from her home village thousands of miles away. She discovered insights about her people that 
she found invaluable for her theological and self understanding. In so doing, she was constructing knowledge of a new kind and in a new way. The Pioneers course did, however, uncover an underside to this pedagogy of creative agency; it expects much of students, and some are overwhelmed by the open-ended process.

\section{CHALlenging With ENCOURAGEMENT}

The final theme to be identified here is the value of challenging a learning community with encouragement. Not only did students identify this as a value of the course, but the teaching team was also immersed in challenging work, requiring us to encourage one another. We engaged in considerable support work with and for the students - doing the ethical and logistical work necessary to conduct oral histories; structuring and teaching the course; helping students gather needed information; and guiding the process as it emerged, as when a group of students needed extra help in finding information, writing their paper, or conducting their interview. Further, teachers and students together discovered that the prophetic pioneers whom we studied often taught with a similar combination of challenge and encouragement. Many were "committed to making a difference in the world," often persevering within oppressive educational and social systems. Most were not willing to see obstacles as the final word. Their lives encouraged us, whether encountered through reading or the awe-inspiring interviews with Anne Streaty Wimberly, Mercedes Iannone, and Ayanna Abi-Kyles.

These seven pedagogical themes are clues for cultivating a spirit for justice and peace. They are not all-inclusive, but they illumine many dimensions of education that inspires and equips people to build a just and peaceful world. Underneath these themes is a spirit of hope, which emerges from the lives of religious educators and educational communities living in diverse times and places of history. That hope, for most of the educators, originates in the Holy, but takes root in ordinary places where people struggle and dream together. To observe and participate in such hope is a gift to be treasured and enacted again and again - a gift that inspires a spirit for justice and peace!

\section{REFERENCES}

Arweck, E. and Nesbitt, E 2004. "Living values: An education program"-from initiative to uptake. British Journal of Religious Education 26(2): 133-49.

Astley, J. 1994. The place of understanding in Christian education and education about Christianity. British Journal of Religious Education 16(2): 90-101.

Barlow, S. 2000. Living water, living conversation: Encountering the other in company with Emmanuel Levinas. Journal of Religious Education 48(4): 22-27.

Bellett, E. 1998. Religious education for liberation: A perspective from Paulo Freire. British Journal of Religious Education 20(3): 133-43. 
Bowman, L. 1996. The enculturation of Holy Child education: Actions not words. Religious Education 91(3): 334-50.

Brelsford, T. 1995. Christological tensions in a pluralistic environment: Managing the challenge of fostering and sustaining both identity and openness. Religious Education 90(2): 174-89.

Chamberlain, G. 2000. Ecology and religious education. Religious Education 95(2): 13450 .

Conway, R. and Watson, B. 1998. Green futures: The purpose and the passion that propels technology, and the implications for religious education. British Journal of Religious Education 20(3): 166-77.

Elliott, P. 1999. Apologetics in a culture war. Journal of Religious Education 47(2): 1923.

Everding, H. and Huffaker, L. 1998. Educating adults for empathy: implications of cognitive role-taking and identity formation. Religious Education 93(4): 413-30.

Everist, N. 2001. Connecting the learning community and vocation in the public world. Religious Education 96(3): 294-309.

Felton, G. 1996. Teaching toward gender and ethnic inclusivity. Religious Education 91(2): 147-59.

Foster, C. 1997. Teaching for belief: Power and pedagogical practice. Religious Education 92(2): 270-84.

Gearon, L. 2002. Human rights and religious education: Some postcolonial perspectives. British Journal of Religious Education 24(2): 140-51.

Grajczonek, J. 2001. "I can't hear you—speak another way": Developing sacramental education in real and relevant ways. Journal of Religious Education 49(4): 24-32.

Grimmitt, M. 1994. Religious Education and the ideology of pluralism. British Journal of Religious Education 16(3): 133-47.

Gur-Ze'ev, I. 2000. Defeating the enemy within: Exploring the link between Holocaust education and the Arab/Israeli conflict. Religious Education 95(4): 373-401.

Heinonen, R. 1995. Imagination and global responsibility from a teaching training viewpoint. British Journal of Religious Education 18(1): 31-38.

hooks, b. 1994. Teaching to transgress: Education as the practices of freedom. New York: Routledge. 
Hookway, S. 2002. Mirrors, windows, conversations: Religious education for the millennial generation in England and Wales. British Journal of Religious Education 24(2): 99-110.

Ingall, C. 1998. The Nashon School: Portrait of a caring community. Religious Education 93(2): 227-40.

Keating, R. 2004. The use of poetry as a pedagogical strategy in religious education to engender a sense of wonder, contemplation and insight. Journal of Religious Education 52(4): 36-40.

Kelly, M. 1998. Solidarity: A foundational educational concern. Religious Education 93(1): 44-64.

Kung, H. 1995. A global ethic and education. British Journal of Religious Education 18(1): 6-21.

Laird, S. 1995. Spiritual education in public schools? Religious Education 90(1): 118-32.

Martin, B. 2000. "Living education": Action research as a practical approach to congregational education. Religious Education 95(2): 152-66.

McArdle, P. 2001. Religious education and the formation of 'great-souled' persons. Journal of Religious Education 49(3): 10-15.

Miller, J. 2003. Using the visual arts in religious education: An analysis and critical evaluation. British Journal of Religious Education 25(3): 200-213.

Mitchell, G. 1995. Principles in the development of religious and moral education in South African schools. British Journal of Religious Education 18(1): 55-8.

Moore, M. 1995a. The myth of objectivity in public education: Intersubjective teaching of religion. Religious Education 90(2): 207-225.

Moore, M. 1995b. Teaching Christian particularity in a pluralistic world. British Journal of Religious Education 17(2): 70-83.

Moore, M. 1998. Poetry, prophecy, and power. Religious Education 93(3): 268-87.

Moy, R. 2000. American racism: The null curriculum in religious education. Religious Education 95(2) 120-33.

Nipkow, K. 1999. Integrity of faith, social justice, and an environmentally friendly future: What kind of interfaith encounter is needed in our schools? British Journal of Religious Education 22(1):25-34. 
O'Grady, K. 2003. Motivation in religious education: A collaborative investigation with year eight students. British Journal of Religious Education 25(3): 214-25.

Orteza y Miranda, E. 1994. Religious pluralism and tolerance. British Journal of Religious Education 17(1): 19-34.

Proffitt, A. 1998. The importance of wonder in educational ministry. Religious Education 93(1): 102-113.

Reiher, P. 1999. Values and educating the virtues: Definitions, documentation sources and issues for the values and attitudes domain of primary religious education in diocesan schools of NSW. Journal of Religious Education 47(4): 9-13.

Sellar, S. 2004. Knowledge reaching beyond reason. Journal of Religious Education 52(2): 30-35.

Siejk, K. 1995. Wonder: The creative condition for interreligious dialogue. Religious Education 90(2): 227-40.

Sikes, P. and Everington, J. 2001. Becoming an RE teacher: A life history approach. Religious Education 24(1): 8-19.

Streib, H. 1998. The religious educator as story-teller: Suggestions from Paul Ricoeur's work. Religious Education 93(3): 314-31.

Treston, K. 2001. Walk lightly upon the earth: Creation centered religious education. Journal of Religious Education 49(3): 2-9.

Willhauck, S. 1996. Liturgy and education for justice in an age of disbelief. Religious Education 91(3): 352-67.

Wimberly, A. 2003. Daring to lead with hope: Association of professors and researchers in religious education presidential address November 3, 2002. Religious Education 98(3): 277-95.

Yob, I. 1995. Spiritual education: A public school dialogue with religious interpretations. Religious Education 90(1): 104-117.

Youniss, J. and Yates, M. 1997. Community Service and Social Responsibility in Youth. Chicago: University of Chicago Press. 


\section{APPENDIX \\ SYLLABUS}

\section{RE520: ISSUES—PROPHETIC PIONEERS IN RELIGIOUS EDUCATION}

Fall 2004

2:30-5:30 p.m.—Bishops Hall 301

\author{
Mary Elizabeth Moore \\ Claire Bischoff
}

The purpose of this class is to explore religious education history, issues, and visions through life story, contextual analysis, and educational theories, practices, and cultural "products." The subjects of the class are people who have pioneered in religious education within the past century, with particular attention to a group of three women who are still living and can tell us their stories. The subjects will include some educators who are widely known, and others who are known within their more particular circles of life and work. The purpose is to discover issues and visions that arise on the margins of religious education discourse and practice, as well as those that arise in the center of notoriety and influence. The telos of the course, taken as a whole, is to analyze the past for the sake of proposing the future.

The value of a person's life work is difficult to discern, much less to evaluate or to become a source of wisdom, if we reflect upon that work from the limited perspectives of our own experience or the dominant religious and educational theories of the day. Oral history provides a way to listen to another closely, to analyze that person's life and work in relation to a larger context, and to draw out insights for theory and practice. Oral history thus contributes to knowledge, for the complexities and nuances of a scholar's life work are more adequately understood within the textures of that person's life history, central values, and social-religious-intellectual contexts. These assumptions reveal why multidimensional research is critical to the study of religious texts, whether biblical texts or lives, events, and literary texts of history. Even so, the actual role of human lives in the making of history, and the role of oral history in the making of historical texts, is yet to be fully explored. As this work emerges, new insights will surely be brought to light. For example, some recent work suggests that oral history was a factor in the composition of early Christian history and gospel accounts of Jesus. One exemplar of that work, Samuel Byrskog, describes the early Christian informants as "living sources of the past," and he attempts what he names as "autopsy as a means of inquiry into the past."

To fulfill the aims of this course, the class will engage in exploration and experimentation. This will involve several kinds of research: reading biographies and works of selected pioneers, conducting oral histories, analyzing life stories and life work, and constructing new visions for religious education. The course, thus, includes the study of materials by and about historical figures in religious education, plus the analysis of videotapes and transcripts of oral histories. It also includes the study and implementation

\footnotetext{
${ }^{3}$ Samuel Byrskog, Story as History — History as Story: The Gospel Tradition in the Context of Ancient Oral History (Tubingen: Mohr Siebeck, 2000), 48; cf: 48-91.
} 
of oral history method-reading about the method, preparing for the logistical and ethical practice of oral history, conducting interviews, and analyzing the fruits of this oral history research for its illumination of the future of religious education.

Funding for conducting the oral histories is provided by the Oral History Project of Women in Theology and Ministry, Candler School of Theology, Emory University, through the generosity of the Wabash Center for Teaching and Learning in Religion and Theology. The rubric of the grant is: "Teaching through Oral History: Composing a Life-Women Changing the Church and Society." Whereas we will not focus only on women in this course, the class's three oral history interviews will be conducted with women. We will do this not only to meet the terms of the grant, but more importantly to discern wisdom as it emerges from those whose work is often less known and valued by the larger academic community. Both the course and the grant are attempts to uncover wisdom from sources and in ways that are not yet mainstream within theology and ministry studies.

\section{Texts:}

Paulo Freire. Pedagogy of Hope: Reliving Pedagogy of the Oppressed. New York: Continuum, 1998, 1992.

Sherna Berger Gluck and Daphne Patai, eds. Women's Words: The Feminist Practice of Oral History. New York: Routledge, 1991.

Elaine J. Lawless. Holy Women, Wholly Women: Sharing Ministries through Life Stories and Reciprocal Ethnography. Philadelphia: University of Pennsylvania, 1994.

Mary Elizabeth Moore, ed. Women Pioneers: Book of Readings for RE 520 Prophetic Pioneers in Religious Education, 2004.

Donald A. Ritchie. Doing Oral History. New York: Oxford University, 2003.

Diane Tickton Schuster. Jewish Lives, Jewish Learning: Adult Jewish Learning in Theory and Practice. New York: UAHC, 2003.

Alan Wieder. Voices from Capetown Classrooms: Oral Histories of Teachers Who Fought Apartheid, New York: Peter Lang, 1991.

\section{Auxilliary Texts:}

Sherna Berger Gluck. An American Feminist in Palestine: The Intifada Years. Philadelphia: Temple University, 1994. 
Paulo Freire. Pedagogy of Freedom: Ethics, Democracy, and Civic Courage, transl. Patrick Clarke. New York: Rowman and Littlefield, 1998.

Myles Horton and Paulo Freire. We Make the Road by Walking: Conversations on Education and Social Change, eds., Brenda Bell, John Gaventa, and John Peters. Philadelphia: Temple University, 1990.

Elaine J. Lawless. Women Escaping Violence: Empowerment through Narrative. Columbia: University of Missouri, 2001.

Alan Wieder. Race and Education: Narrative Essays, Oral Histories, and Documentary Photography. New York: Peter Lang, 1997.

\section{Responsibilities:}

Students are asked to fulfill the following responsibilities as we proceed through this semester:

(1) Full reading and participation: This is a class that expects much of the students, both for your own learning and for the learning of the entire community. Further, the expectations are high because the results of our work will be included in the archives of the Pitts Theology Library. The Oral History Project-funded in Phases Two and Three by The Wabash Center for Teaching and Learning in Theology and Religion — is in three phases. Phase One involved gathering oral histories through presentations and interviews sponsored by the Women in Theology and Ministry Program, 2000-2002. The present Phase Two is "Teaching through Oral History: Composing a Life-Women Changing the Church and Society." You are part of the learning process of this phase, as well as the collecting process. All of the interviews and materials gathered by our class will be gathered into archival form for Pitts Library. Archivists there will eventually catalogue these as part of the permanent collection. This means that your work in this class-reading and understanding texts and archival material, conducting oral history interviews, and analyzing the interviews and works of the interviewees - will be critical for your personal and communal learning, and also for posterity.

In addition to the oral histories themselves, all of the reading and special assignments of the class are intended to build toward maximal learning for all of us and toward the best possible oral histories that we can do in the framework of a single class. For this reason, please plan to talk with Mary Elizabeth Moore about missed classes, so that you can have an individual discussion of the readings and other assignments for that class.

(2) Study of, preparation for, and implementation of oral histories: You will be asked to study the methods of oral history, and to plan and implement the details 
of the class's oral history collections. Details of this responsibility are outlined in the class schedule.

(3) Portrait Paper: The first paper- "Portrait Paper"- describes and analyzes the contribution of a prophetic pioneer in religious education. This person may be one whose biography and work we have read or another person whom you identify. This paper will be 5-7 pages in length (typed, double-spaced), and shall include: (1) a description of the person's life, context, and religious education work; (2) a critical evaluation of the person's contributions; and (3) your own projections for religious education based on the person's influence. Your research may include library research (works by and about the subject of your study); interviewing if possible and appropriate, and review of any oral histories that you are able to access on-line; in the Center for Ecumenical and Multicultural Education (CEME, located in Religious Education Office, 310 Bishops Hall), or in local libraries. The CEME has videotaped interviews with Olivia Pearl Stokes (work focused on building global and ecumenical bridges); Iris Cully (work focused on the Bible, children, and spirituality); Randolph Crump Miller (influenced by philosophy of religion and process theology); Campbell Wyckoff (particularly influential on curriculum theory); Paul Irwin (focused on youth. youth ministry, and the arts); and others. Your portrait paper is due on October 13, on which day we will discuss the papers in class. Please bring 5 copies with you - one for each member of a small group, and one for the teachers.

(4) Methods Paper: The second paper- "Methods Paper"- is done with your planning team, and it outlines the purposes, procedures, and background that your team has developed for the oral history of a religious educator. This educator will be pre-selected by the instructor, but the groundwork and preparation for the interview will be conducted by your team. The paper (7-8 typed, double-spaced pages) needs to include: (1) introduction to the life of your interviewee;

(2) introduction to her life work; (3) description of the purposes of your oral history study of this person; and (4) description of the procedures you will follow and the questions you will ask. You will have some time to work on this paper in class on October 20 and 27; however, you will need to organize with your group for people to work outside of class as well (individually and/or in the total group). The paper is due in penultimate draft on October 27, and in final draft on November 3 .

Note regarding the Methods Paper: Some of the interview protocol is prescribed by the Wabash grant. You will need to build upon these givens and make selections and modifications as you see fit for your particular purposes. The semi-structured interview is defined in the grant protocol as quoted below. Please remember, however, that the Oral History team will conduct further interviews with the three women in other venues. This means that you need not cover all of the protocol topics in your class interviews. The protocol reads as follows:

Semi-structured Interviews will begin with asking the women one question, "Tell us some of the most significant moments in your life and work." Particular questions will include: 
- What are some of the most significant events in your life journey? Why have these particular events been significant?

- Who have been some of the most significant people, communities, and places in your life? Why?

- How would you describe your ministry and changes in your ministry over time? How has your ministry been shaped by your life experiences and distinctive personality? How has your ministry, in turn, shaped you as a person?

- As you look back on your life thus far, what do you see as the most important contributions you have made? Why do these stand out as important?

- What crises have you faced in your personal life and ministry?

- What crises have your churches and other communities faced?

- What have been major moments of struggle for you? These might include moments of losing faith, disrupted relationships, self-doubts or public upheaval.

(5) Final paper: Write a final paper focused on your visions for religious education, as influenced by the prophetic pioneers we have studied (14-16 typed, doublespaced pages). Building on the semester's work, including the library research and oral histories, describe what you have learned - particularly what you have learned from the pioneers about human existence, Christian vocation, and religious education - and how that shapes your vision. Your methods paper can be incorporated into this final paper, or you can present a modification of that paper, including the four (1-4) elements described above for inclusion in that paper. To that initial work, please add sections of analysis, interpretation, and constructive engagement to this final paper: (5) analyze the dominant themes, purpose, and contributions of this person's (persons') life work in relation to her social-religious-intellectual contexts; (6) evaluate her primary contributions, and her particular contributions in relation to human existence, Christian vocation, and religious education; (7) draw from this analysis and evaluation to construct a vision of religious education that is compelling for your vocation and the vocation of your community, taking account of the contexts in which you live and to which you are called.

(6) Presentation: Your presentation on December 1 is to be a lively portrayal of your work (5-7 minutes) - a creative distillation of your central insights, which anticipates the more thoroughly detailed work of your final paper. The purpose is to distill your own thinking and contribute wisdom to the class as we close the semester together. The focus of your presentation is to be the last three sections of your final paper - analysis, interpretation, and visioning, with emphasis on your visioning. The presentation is not a rough draft of your paper, however. The papers are not due until December 9, but the class presentation will help you move toward the paper, while also sharing your wisdom with the class. We ask that you give your colleagues a thoughtful and creative distillation of your central insights. Please share also how those insights are informed and deepened by the 
prophetic pioneers we studied this semester - either one pioneer or a consortium of them. You may focus on: the person your group interviewed, all three of our class's interviewees, the person on whom you focused your portrait paper, and/or other pioneers whom we studied this semester. Whatever your focus, please do the following:

(a) Analyze : Give in-depth attention to the pioneers' lives and work. Analyze the dominant themes, purpose, and contributions of the persons' life work in relation to their social-religious-intellectual contexts (\# 5 for paper).

(b) Evaluate and interpret: Evaluate the persons' primary contributions, as well as contributions to deepened understandings of human existence, Christian vocation, and religious education (\# 6 for paper).

(c) Envision: Offer a constructive vision of religious education. The vision will hopefully be compelling for your vocation and the vocation of your community, taking account of the contexts in which you live and to which you are called (\# 7 for paper).

\section{Grading Scale :}

Portrait Paper $20 \%$

Methods Paper 20\%

Oral History Interview $\quad 10 \%$

Final Paper \& Presentation $40 \%$

Participation $\quad 10 \%$ (can also influence final grades on the borderline)

\section{Class Schedule:}

September 1 INTRODUCTION:

- "Talk Story"-Reflecting on the history of our personal commitments to and perspectives on religious education

- Surveying the history of religious education

- Surveying possibilities in oral history-purposes, rationale, and jumping into the deep waters of oral history approaches to the study of prophetic pioneers.

September 8 EXEMPLARS: Paulo Freire. Study of selected prophetic pioneers and their contributions to religious education, in relation to their life stories and social-religious-intellectual contexts.

Reading: Paulo Freire, Pedagogy of Hope: Reliving Pedagogy of the Oppressed. Read this text, with the following questions in mind: 
(1) How does this text address you? What inspires, informs, inhibits, and/or transforms you in the reading? (This is a more personal, existential question than the others.) What were the central educational commitments of Freire, and how were these shaped by and influences on his life journey and contextual realities? (This is primarily a descriptive and analytic question.)

How do you evaluate Freire's contribution in light of this analysis? (This question and the next are more interpretive.) What do you learn from Freire about human existence, Christian vocation, and religious education theory and practice? What visions of religious education are stirred for you by this study? (This is a playful and visionary question.)

Presentation: Read a brief selection from one of Freire's latest publications (distributed in class). Prepare to work with a group in dramatizing this selection for the rest of the class. The presentations themselves will be prepared during class time.

\section{September 15 Women Pioneers}

Reading: Mary Elizabeth Moore, ed., Women Pioneers: Book of Readings. Read two of these biographies, asking the five questions (above) and making notes for class discussion. These are not notes to submit, but notes for reference as the class discusses the larger text. (We will also continue the Freire analysis in class on this day.)

September 22 THE ART OF ORAL HISTORY: Purposes and Values

Reading: Elaine Lawless, Holy Women: Wholly Women

Read pp. 57-83, 127-154, 201-241, 267-282, and at least five of the women's stories that are sprinkled through the book. Skim pp. 242-266.

September 29 Methods and Preparation

Reading: Donald A. Ritchie, Doing Oral History

Introduction-Read in entirety (pp. 11-18)

Chapter 1- An Oral History of Our Time-Read in entirety (pp. 19-46)

Chapter 2- Setting Up an Oral History Project-Read sections on

Equipment, Processing, and Legal Concerns (pp. 57-79). Skim the

final section on Archiving and the Internet (pp. 79-83)

Chapter 3- Conducting Interviews-Read in entirety (pp. 84-109)

Chapter 4- Using Oral History in Research and Writing-Read Oral

Evidence section (pp. 117-128)

Chapter 5- Videotaping Oral History-Read in entirety (21 pages)

Chapter 6- Presenting Oral History in Archives and Libraries-Skip.

Chapter 7- Teaching Oral History-Skim introduction and Oral History in Elem. and Sec. Schools (188-206) and Institutional Review Boards (215-221)

Chapter 8- Presenting Oral History-Skim in its entirety. 
Note: Total pages of reading $=116$; pages for skimming $=61$.

Preparation for Oral Histories: By this date, go onto the Emory University Institutional Review Board website, and take the exam that is offered there. This exam is required of all faculty, staff and students of Emory University who are involved in research with human subjects. The purpose and value of the material and the testing process are explained on the website; the values will also become clear to you as you study the materials. You will need to take the following modules: Introduction, 1-6, 17, and EUSOM. Upon your completion, please present to Mary Elizabeth Moore or Claire Bischoff the verification that IRB e-mails you. [Note: A more detailed explanation is appended to this syllabus. You will see that the modules may be studied online or printed for your study. Further, they may be taken and re-taken until you feel that you have learned the material well and have received the requisite score. The address is: http://www.emory.edu/IRB or irb@emory.edu.]

October 6 DISCOVERING EDUCATIONAL WISDOM THROUGH ORAL HISTORY:

Reading: Mary Elizabeth Moore, ed., Women Pioneers: Book of Readings. Read the book in its entirety this time, and respond to the five questions that we are using throughout the semester:

(1) How do these biographies address you? What inspires, informs, inhibits, and/or transforms you in the reading?

(2) What were the central educational commitments of these womenanalyzed distinctively and as a group? How were these shaped by and influences on their life journeys and contextual realities?

(3) How do you evaluate the women's contributions in light of your analysis?

(4) What do you learn from these women about human existence, Christian vocation, and religious education theory and practice?

(5) What visions of religious education are stirred for you by this study?

October 13 Discussion of Portrait Papers. The description of this paper is in the "Responsibilities" section of the syllabus (above). Please bring 5 copies of your paper to class on this day, as we will discuss the papers during the class session. The class discussion will focus largely on discovering educational wisdom from the subjects of your papers and from your own analyses and interpretations.

October 20 HUMAN VALUES OF ORAL HISTORY

Readings: Readings on this day will be assigned later, based on issues and questions that have arisen in the class. They will be drawn from Sherna Berger Gluck and Daphne Patai, eds., Women's Words and Alan Wieder's Voices from Capetown Classrooms.

October 27 Readings of works by the woman whom your group will interview(to 
be selected by the group itself).

Readings: Diane Tickton Shuster, Jewish Lives, Jewish Learning. Read the Introduction and three chapters of your choice. Read to discern the method, appreciate the stories, and glean insights for teaching and learning religion with adults.

Methods Paper penultimate draft due on this day. Please bring copies for everyone in your small group, as well as copies for Claire Bischoff and Mary Elizabeth Moore. Some class time will be set aside for groups to identify gaps and discuss final touches, and for you to submit the penultimate draft for feedback from the faculty. The faculty will give send you feedback by e-mail on or before Saturday, October 31. This will give the group some time to polish the papers before the due date on November 3.

November 3 Readings of works by the two women whom the other groups will interview (to be assigned later).

Methods Paper due. You will be asked to present parts of your paper for the class on this day, and we will do planning for the two interview sessions on November 10 and 17.

November 10 INTERVIEWS

November 17 INTERVIEWS

November 24 NO CLASS-Thanksgiving Week

December 1 Presentations of Analyses and Visions

December 9 Final Papers due

\section{APPENDIX:}

\section{Instructions for IRB :}

Go to http://www.emory.edu/IRB

On the right hand side of the page, under the heading in red "New CITI Course Format," click on the link where it is written "Click HERE for CITI program information."

Then scroll down to where it is written "Go to http://www.citiprogram.org to register and log into the CITI Program" and click on this link to register for the modules.

When you get to the CITI page, you will need to register to receive a user name and password. On the registration form, choose "interviewer" for your role in human research. After submitting your registration information, choose Group 2 on the next page. You can then click on "Basic Course" to begin. 
You can study the modules on-line or print them. The quizzes must be taken on-line. You may retake them until you have learned the material well and have received the requisite score. The site will keep track of the modules you have completed as well as your scores. You need to get $80 \%$ correct on the quizzes for the required modules.

You do not need to take all of the modules in one sitting. When you leave the site, be sure to log off. To continue your work on the modules, return to http://www.citiprogram.org.

Below are the modules that you will need to take:

\begin{tabular}{l|l|l|l|l|l|l}
\hline INTRO & Introduction \\
SHB01 & History and Ethical Principles - SBR \\
SHB02 & $\begin{array}{l}\text { Defining Research with Human Subjects - } \\
\text { SBR }\end{array}$ \\
\hline SHB03 & $\begin{array}{l}\text { The Regulations and The Social and } \\
\text { Behavioral Sciences - SBR }\end{array}$ \\
& $\begin{array}{l}\text { Assessing Risk in Social and Behavioral } \\
\text { SHB04 }\end{array}$ & $\begin{array}{l}\text { Sciences - SBR } \\
\text { SHB05 }\end{array}$ & Informed Consent - SBR \\
SHB06 & Privacy and Confidentiality - SBR \\
SHB17 & $\begin{array}{l}\text { Conflicts of Interest in Research Involving } \\
\text { Human Subjects }\end{array}$ \\
EUSOM & Emory University
\end{tabular}

You will need to present to Mary Elizabeth Moore or Claire Bischoff the verification of completion that the IRB will send you by e-mail. 